\title{
An Estimation of Soil Erosion Rate Hot Spots by Integrated USLE and GIS Methods: a Case Study of the Ghiss Dam and Basin in Northeastern Morocco
}

\begin{abstract}
Soil erosion is a major factor leading to dams' siltation and reducing their storage capacity. This study mapped the hot spots of soil erosion areas to predict the soil erosion/siltation in the Ghiss basin/dam (northeastern Morocco). In this context, various data has been prepared in the geographical information system for the estimation of soil erosion by integrating the universal soil loss equation (USLE). The result of this study revealed that soil loss rate ranges between 0 and $19 \mathrm{t} \cdot \mathrm{ha}^{-1} \cdot \mathrm{yr}^{-1}$. Therefore, the hot spots in the soil erosion area are to be found upstream, potentially leading to dam siltation over time. To avoid Ghiss dam siltation, we suggest terrace farming and reforestation in the soil erosion area hot spots.
\end{abstract}

Keywords: reforestation, Rif, risk, soil loss, terrace farming

Received: 22 September 2021; accepted: 3 February 2022

(C) 2022 Authors. This is an open access publication, which can be used, distributed and reproduced in any medium according to the Creative Commons CC-BY 4.0 License.

1 Abdelmalek Essaâdi University, The Faculty of Sciences and Technique of Al-Hoceima, The Department of Earth and Environmental Sciences, Tétouan, Morocco, email: geomorad@gmail.com, (D) https://orcid.org/0000-0002-9273-2764

2 Abdelmalek Essaâdi University, The Faculty of Sciences and Techniques of Tanger, The Department of Geology, Tétouan, Morocco, email: tmourabit@gmail.com, (1) https://orcid.org/0000-0002-5542-7074

3 Abdelmalek Essaâdi University, Al Hoceima National School of Applied Sciences, Laboratory of Water and Environmental Engineering, Tétouan, Morocco, email: bourjilaabdelhak@live.fr, (D) https://orcid.org/0000-0003-2592-6179

4 Abdelmalek Essaâdi University, Al Hoceima National School of Applied Sciences, Laboratory of Water and Environmental Engineering, Tétouan, Morocco, email: omars3idi@gmail.com, (1) https://orcid.org/0000-0002-1635-5784

5 Abdelmalek Essaâdi University, The Faculty of Sciences of Tétouan, The Department of Geology, Tétouan, Morocco, email: errahmouniali@gmail.com, (1) https://orcid.org/0000-0003-0303-8971

6 Abdelmalek Essaâdi University, Al Hoceima National School of Applied Sciences, Laboratory of Engineering and Application Sciences, Tétouan, Morocco, email: Fouad.elmrzkioui@etu.uae.ac.ma, (1) https://orcid.org/0000-0002-5656-6156

7 Abdelmalek Essaâdi University, The Faculty of Letters and Human Sciences of Tetouan, Department of Geography, Tétouan, Morocco, email: elmoussaoui.mhmd@gmail.com, (D) https://orcid.org/0000-0003-3864-3135 


\section{Introduction}

Soil erosion is a major contributing factor in dam siltation [1]. In Morocco, soil erosion rates for a basin area of 71 million hectares are $1.408 \mathrm{t} \cdot \mathrm{ha}^{-1} \cdot \mathrm{yr}^{-1}$, which has led to dam siltation and the reduction of the storage capacity of the dams by $0.56 \%$ every year [2], with negative economic (1 billion USD) (Tab. 1) and environmental consequences $[2,3]$. Furthermore, it has a negative impact on hydropower and agricultural activities [4-6]. The siltation phenomenon of the dam basin in Morocco has been studied by many researchers [7-11], and it has been found that more than $65 \mathrm{Mm}^{3} \cdot \mathrm{yr}^{-1}$ of sediment affects the dams. Therefore, the siltation of reservoirs has resulted in serious loss of storage capacity and reductions in their lifespan [10], such as three check dams in the Msoun basin (eastern Pre Rif), were totally filled with sediment in less than seven years [9].

Table 1. Soil loss costs according to watersheds (DH - Moroccan dirham)

\begin{tabular}{|l|c|c|c|c||}
\hline \multicolumn{1}{|c|}{ Dam } & $\begin{array}{c}\text { Area watershed } \\
{\left[\mathrm{km}^{2}\right]}\end{array}$ & $\begin{array}{c}\text { Reservoir capacity } \\
{\left[\mathrm{Mm}^{3}\right]}\end{array}$ & $\begin{array}{c}\text { Siltation } \\
{\left[\mathrm{Mm}^{3} \cdot \mathrm{yr}^{-1}\right]}\end{array}$ & $\begin{array}{c}\text { Money loss } \\
{[\text { million DH }]}\end{array}$ \\
\hline Mohamed V & 49,920 & 465 & 10.00 & 1,815 \\
\hline Ouahda & 6,153 & 3,730 & 18.50 & 1,462 \\
\hline Hassan I & 1,670 & 254 & 2.90 & 752 \\
\hline Moulay Youssef & 1,441 & 175 & 2.60 & 735 \\
\hline O. Makhazine & 1,820 & 772 & 4.60 & 730 \\
\hline Idriss I & 3,680 & 1,173 & 2.20 & 659 \\
\hline Allal Fassi & 5,765 & 81 & 1.20 & 629 \\
\hline El Kansera & 4,540 & 265 & 1.40 & 586 \\
\hline Bine El Ouidane & 6,400 & 1,300 & 5.00 & 549 \\
\hline Mansour Eddahbi & 15,000 & 505 & 4.70 & 390 \\
\hline M.B.A. Khattabi & 780 & 34 & 1.30 & 316 \\
\hline Lalla Takerkoust & 1,707 & 68 & 0.50 & 293 \\
\hline Sidi M.B. Abdellah & 9,800 & 477 & 1.70 & 258 \\
\hline Y.B. Tachfine & 3,784 & 303 & 1.43 & 188 \\
\hline Aoulouz & 4500 & 100 & 2.10 & 127 \\
\hline Al Massira & 28,500 & 2,747 & 2.50 & 118 \\
\hline Hassan Eddakhil & 4,400 & 343 & 1.17 & 113 \\
\hline Ibn Batouta & 178 & 36 & 0.56 & 113 \\
\hline Nakhla & 107 & 6.30 & 100 \\
\hline
\end{tabular}


Table 1. cont

\begin{tabular}{|c|c|c|c|c|}
\hline Abdelmoumen & 1,300 & 213 & 0.23 & 55 \\
\hline Hachef & 220 & 300 & 0.50 & 48 \\
\hline Mellah & 1,800 & 8 & 0.15 & 12 \\
\hline Total & 153,465 & 13,355 & 65.54 & 10,048 \\
\hline
\end{tabular}

Source: [2]

The Mohamed Ben Abdel Karim Khattbi (MBAK) (Tab. 1) dam in Al-Hoceima Province is considered one of the dams most prone to siltation in Morocco, yet it constitutes the only source of water for the city of Al Hoceima and the surrounding urban centers [12]. To avoid drinking water shortage problems, another dam is under construction in the Ghiss basin.

Soil erosion is very high in the Rif region of Morocco, with rates sometimes reaching 30-60 $\mathrm{t} \cdot \mathrm{ha}^{-1} \cdot \mathrm{yr}^{-1}[13,14]$. In this context, our objective in this study is the estimation of soil loss in the Ghiss basin, and its impacts on the Ghiss dam siltation by integrating the universal soil loss equation (USLE) and geographic information system (GIS). Therefore, this study can provide information on annual soil loss and hot spot areas in the watershed and its location of the Ghiss dam to take the necessary interventions [13]. In Morocco, many researchers have studied the vulnerability of watershed erosion using the USLE empirical model [11, 13, 16-18], their results of soil loss estimation varying from one basin to another. This difference is due to variations in the physical characteristics of each basin [18]. Various data have been used in this model such as rainfall erosivity $(R)$ factor, soil erodibility $(K)$ factor, and use land cover data, cover, and management $(C)$ factor, conservation practice $(P)$ factor, slope length, and steepness (LS) factor, by integrating of all these factors, we can compute annual soil loss $\left(\mathrm{t} \cdot \mathrm{ha}^{-1} \cdot \mathrm{yr}^{-1}\right)$ in the Ghiss basin.

\section{The Study Area}

The Ghiss basin located in the central Rif of Morocco (Fig. 1), its delimitation by GIS provides a total area of 84,595 ha, its altitude is between 2 and $2055 \mathrm{~m}$, and it decreases gradually northeast. Also, annual precipitation (30 years) decreases gradually northeast from 953 to $270 \mathrm{~mm} \cdot \mathrm{yr}^{-1}$, and its slope is between 0 and 52 degrees. The study area stretches from latitude 35.19 north to 34.80 longitude 4.44 to 3.83 west. The main stream is the Oued Ghiss, which is around $80 \mathrm{~km}$ in length [20] and flows into the Mediterranean Sea, its water is a source of irrigation for many farmers. Recently, a dam project has been introduced (Fig. 2) in the study area in order to provide potable water to the population of $\mathrm{Al} \mathrm{Hoceima}$ and the surrounding urban centers. This is especially important given the end of the validity period of the 
MBAK dam because of the siltation problem. However, to avoid the siltation phenomenon due to high soil erosion, by anti-erosion works in the Ghiss watershed, as a first step it is necessary to estimate the annual soil loss of the Ghiss watershed.

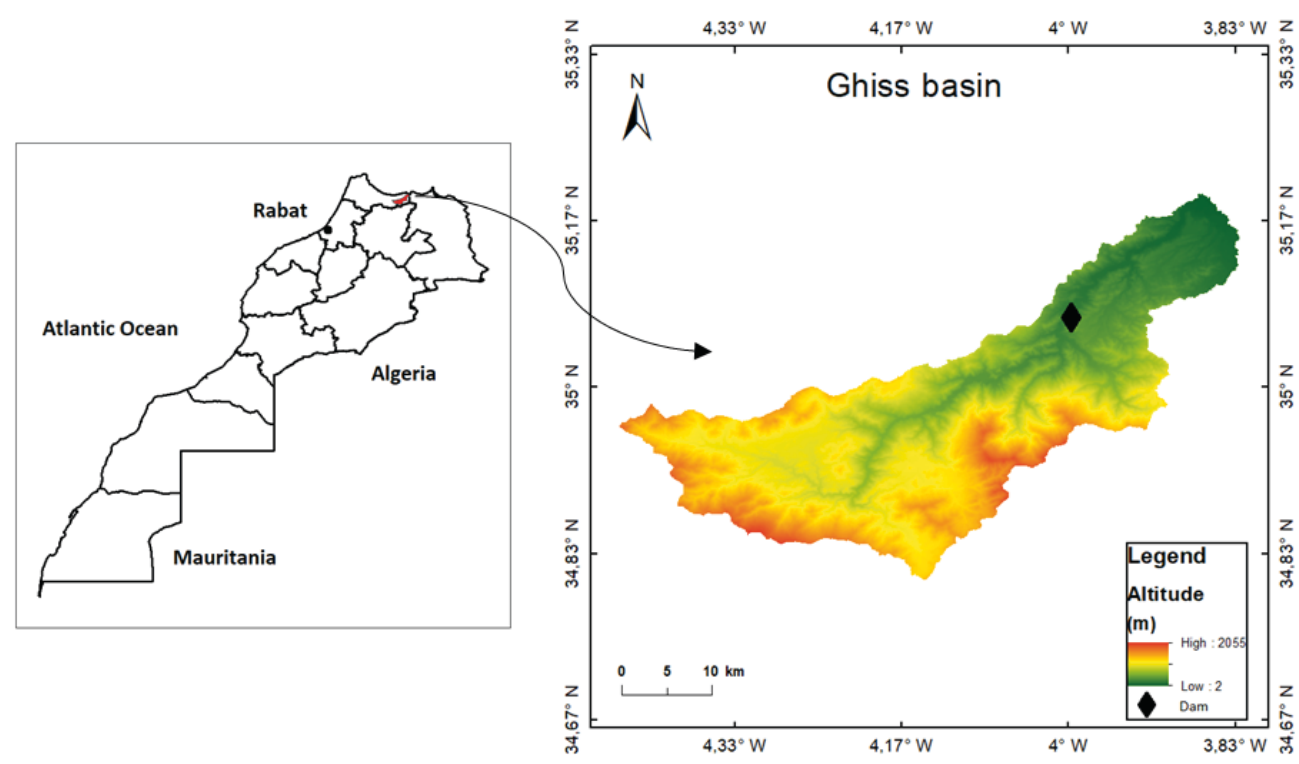

Fig. 1. Localization of study area

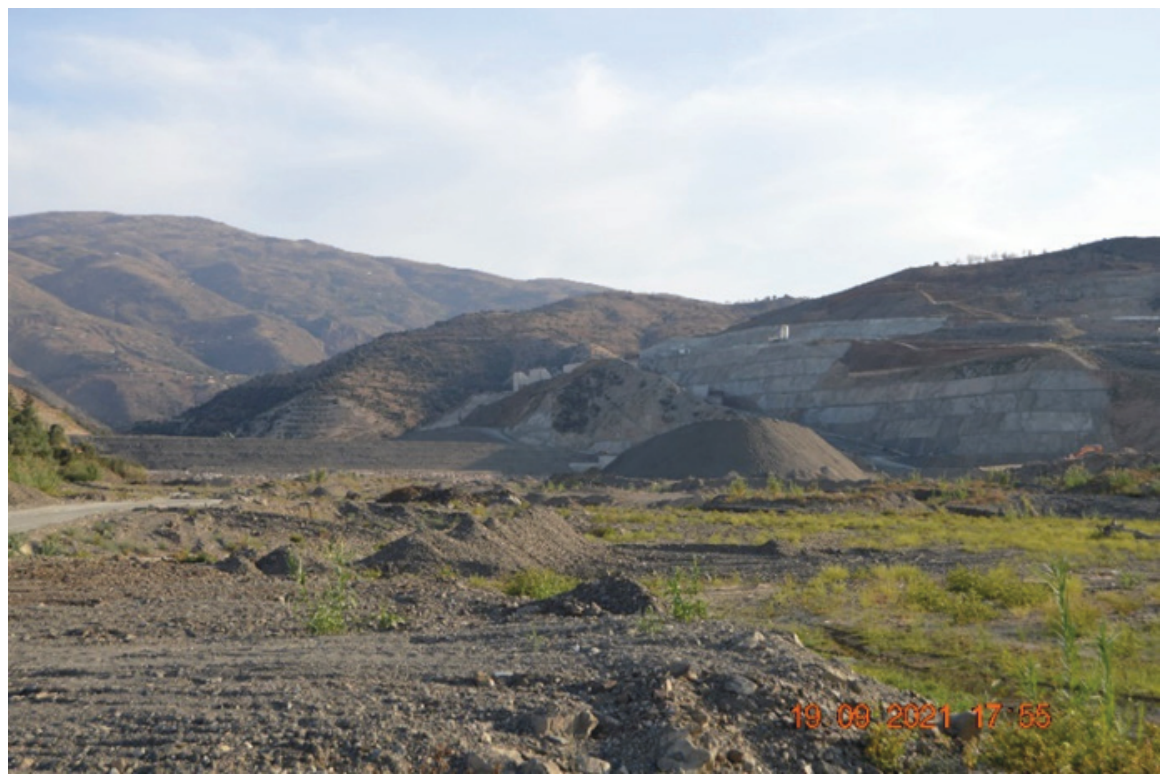

Fig. 2. Dam under construction in the Ghiss basin 


\section{Materials and Methods}

The estimation of soil loss was quantified using the USLE model Equation (1) proposed by Wischmeier and Smith [16], and it is applied globally [11, 17, 21-28] by employing five parameters using several data sources and integrating GIS:

$$
A=R \cdot K \cdot L S \cdot C \cdot P
$$

where:

$$
\begin{aligned}
& \left.A \text { - annual soil losses [t } \cdot h \mathrm{ha}^{-1} \cdot \mathrm{yr}^{-1}\right], \\
& \left.R \text { - factor of rainfall erosivity [MJ } \cdot \mathrm{mm} \cdot \mathrm{ha}^{-1} \cdot \mathrm{h}^{-1} \cdot \mathrm{yr}^{-1}\right], \\
& \text { - factor of soil erodibility }\left[\mathrm{t} \cdot \mathrm{ha} \cdot \mathrm{h} \cdot \mathrm{ha}^{-1} \cdot \mathrm{MJ}^{-1} \cdot \mathrm{mm}^{-1}\right] \\
& L S \text { - factor of length and gradient of slope, } \\
& \text { - factor of land cover, } \\
& P \text { - factor of conservation practices. }
\end{aligned}
$$

The methodology adopted in the study is shown in Figure 3.

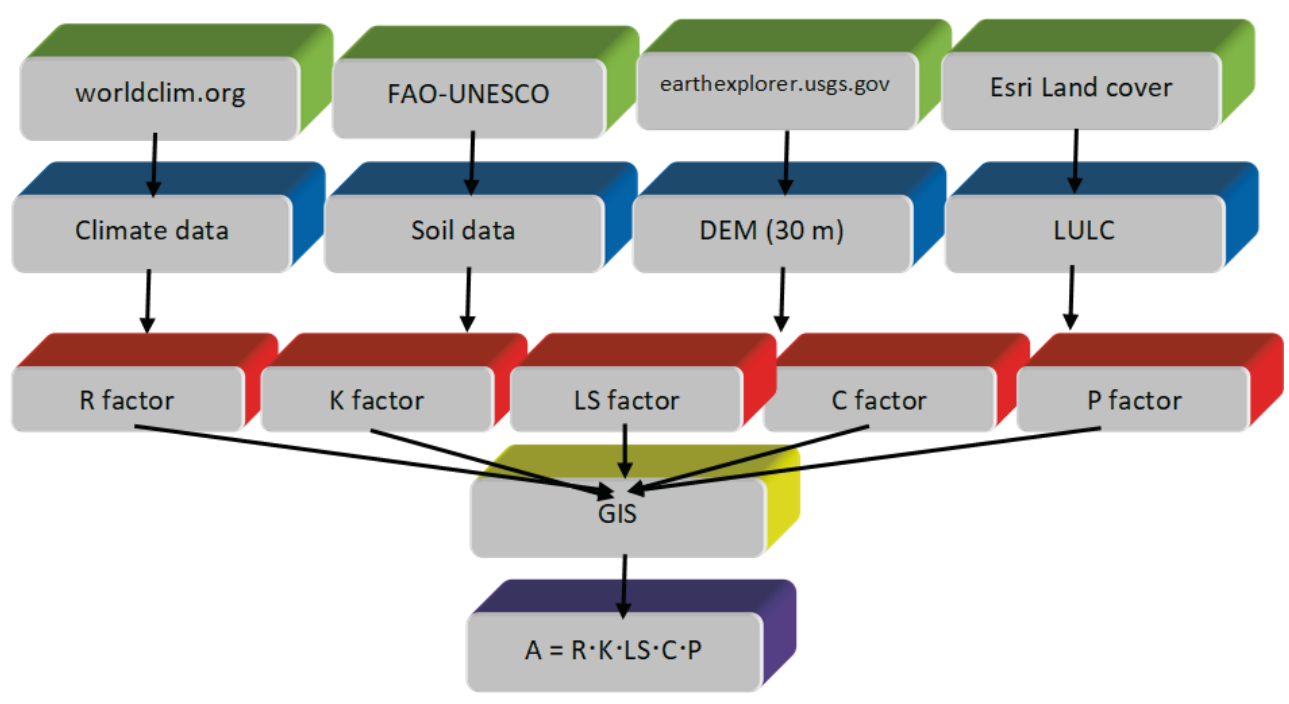

Fig. 3. Flowchart of the methodology

\subsection{Rainfall Erosivity Factor $(R)$}

This was defined by Wischmeier and Smith [19] as the product of the total kinetic energy multiplied by the maximum 30 min rainfall intensity, and it is considered to be a driver of soil erosion processes [17]. There are many methods to calculate the annual rainfall erosivity factor $(R)[17,21,22,25-28]$. For this study, we used the Equation (2) of Nguyen [29] to measure the $R$ factor based on annual precipitation (30 years), and the data was downloaded through the WorldClim site [30]. 
The $R$ factor value in the study area varies from 88 to 262 (Fig. 4). A high $R$ factor value is to be found upstream, and a low $R$ factor downstream:

$$
R=0.548257 \cdot P-59.9
$$

where $P$ is the annual precipitation $[\mathrm{mm}]$.

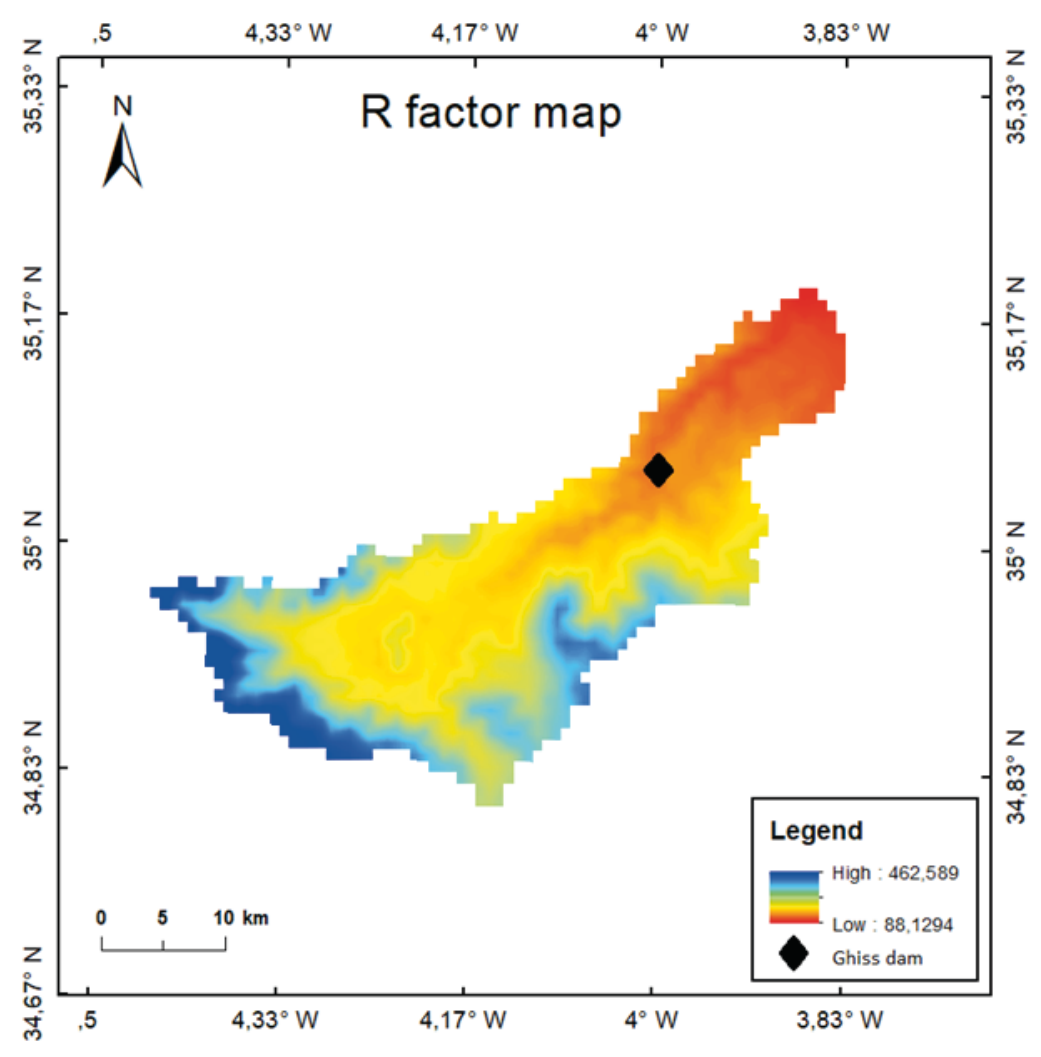

Fig. 4. $R$ factor of the study area

\subsection{Soil Erodibility Factor $(K)$}

The soil erodibility factor $(K)$ represents the susceptibility of soil or surface material to erosion [26], it is strongly related to the physical properties of the soil [31], such as soil organic matter, and percentage of sand, silt, and clay in the soil [32]. According to the FAO soil map of the world, two different soil types were identified in the study area: Chromic Luvisols (LC) and Calcaric Fluvisols (JC) (Tab. 2). The soil types were assigned $K$ factor values from the FAO soil classification to obtain the $K$ factor map (Fig. 5), which shows that the majority have a low $K$ factor. 
Table 2. Different soil type and their corresponding $K$ factor

(OM - organic material)

\begin{tabular}{|c|c|c|c|c|c||}
\hline \hline Soil symbol & Sand [\%] & Silt [\%] & Clay [\%] & OM [\%] & $K$ \\
\hline \hline LC & 39.6 & 39.9 & 20.6 & 1.118 & 0.34 \\
\hline JC & 64.3 & 12.2 & 23.5 & 1.083 & 0.20 \\
\hline
\end{tabular}

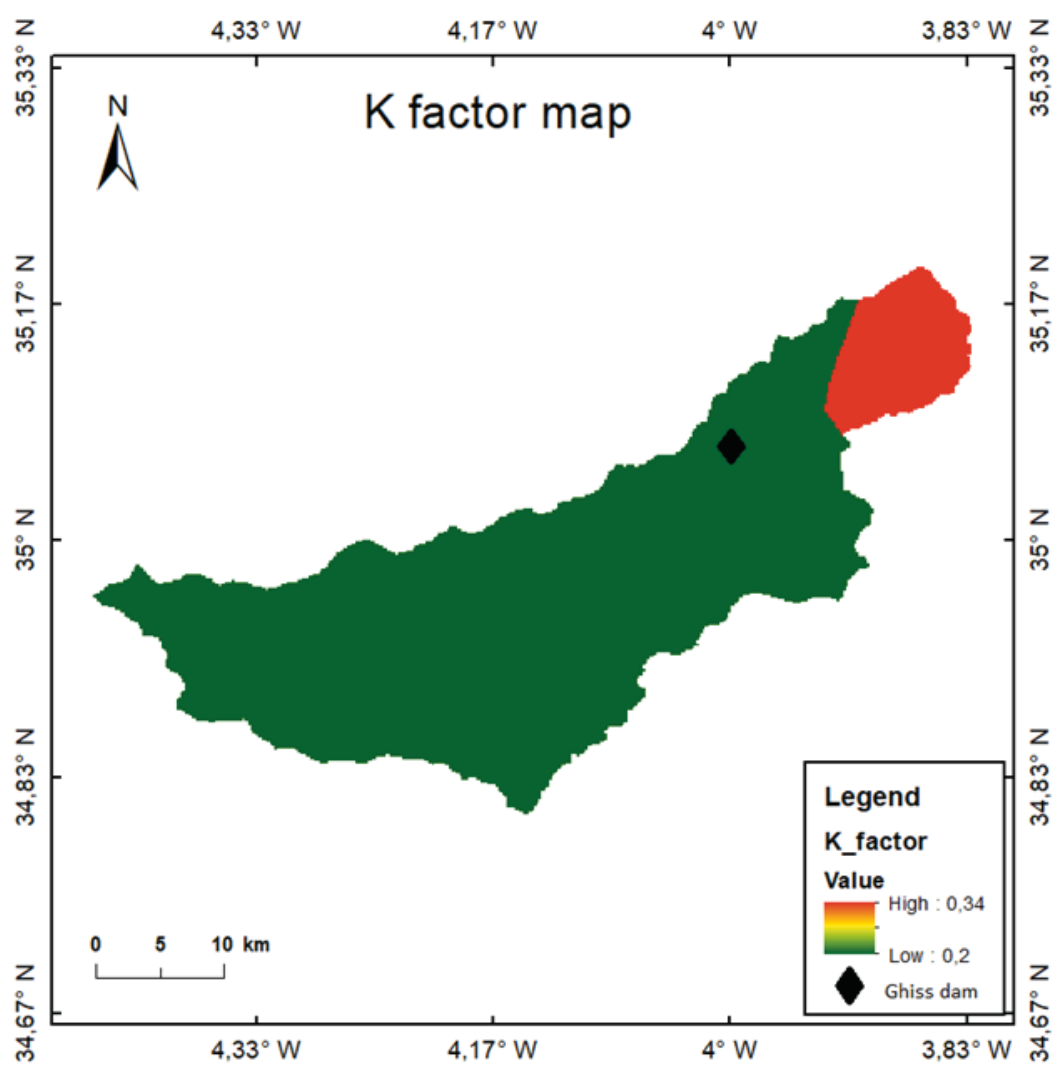

Fig. 5. $K$ factor of study area

\subsection{Slope Length $(L)$ and Steepness $(S)$ Factor (LS Factor)}

It reflects the effect of length and steepness on erosion. The data used to calculate this factor is DEM $(30 \mathrm{~m})$ downloaded from Earth Explorer to extract the topo-hydrographical configuration (Fig. 6). The empirical Equation (3) adopted to calculate $L S$ factor is used by many researchers and was proposed by Moore and Wilson [33]:

$$
L S=((\text { flow accumulation } \cdot \text { cell size }) 0.4 / 22.13) \cdot((\text { sin slope }) 1.3 / 0.0896)
$$




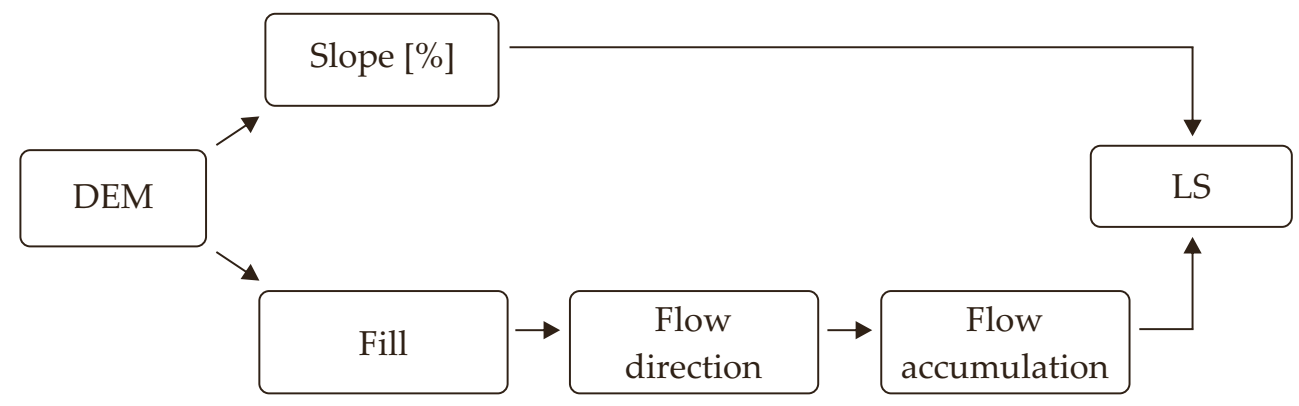

Fig. 6. Flowchart of $L S$ factor

The LS factor value in the study area varies from 0 to 22 (Fig. 7).

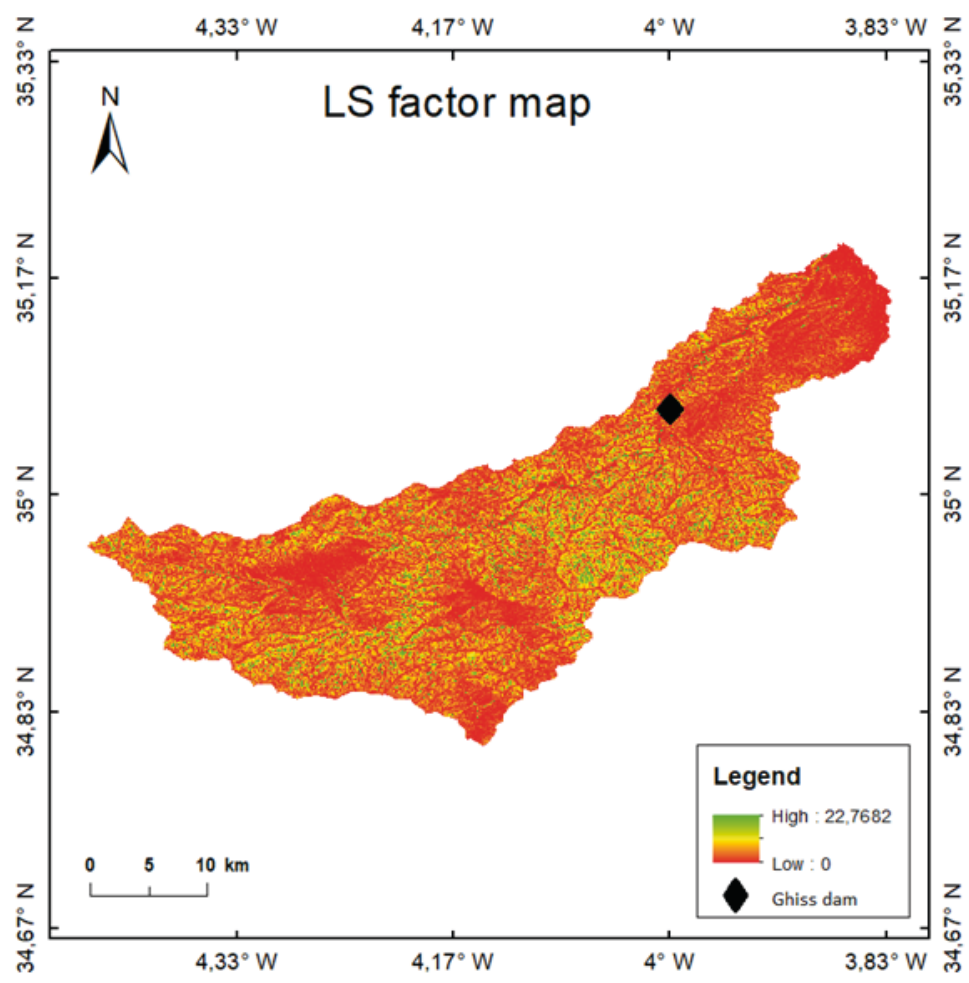

Fig. 7. LS factor of study area

\subsection{Cover Management Factor (C)}

This is one of the most important factors in the USLE equation that controls soil loss [34]. The principal land cover classes include scrub $(71 \%)$, urban $(9 \%)$, crops $(11 \%)$, trees $(1.4 \%)$, and bare ground $(1.7 \%)$, each land cover was assigned 
with its corresponding $C$ factor as per Hurni [35] and Reusing et al. [36]. Therefore, the analysis of the cover factor distribution (Tab. 3) shows that more than half of the watershed $(71 \%)$ has moderate protection levels $(0.2)$. The results showed that the $C$ factor in the research area ranged from 0 to 0.2 (Fig. 8).

Table 3. Different land cover classes and their corresponding $C$ factor

\begin{tabular}{||l|c|c|c||}
\hline \multicolumn{1}{|c|}{ Land cover class } & Area $\left[\mathrm{km}^{2}\right]$ & Area [\%] & $C$ \\
\hline \hline Water & 0.7973 & 0.094249 & 0.00 \\
\hline Trees & 46.3792 & 5.482509 & 0.01 \\
\hline Grass & 0.3315 & 0.039187 & 0.05 \\
\hline Crops & 94.5291 & 11.17433 & 0.15 \\
\hline Scrub & 608.9033 & 71.97877 & 0.20 \\
\hline Urban & 80.0374 & 9.461261 & 0.004 \\
\hline Bare ground & 14.9707 & 1.769694 & 0.05 \\
\hline
\end{tabular}

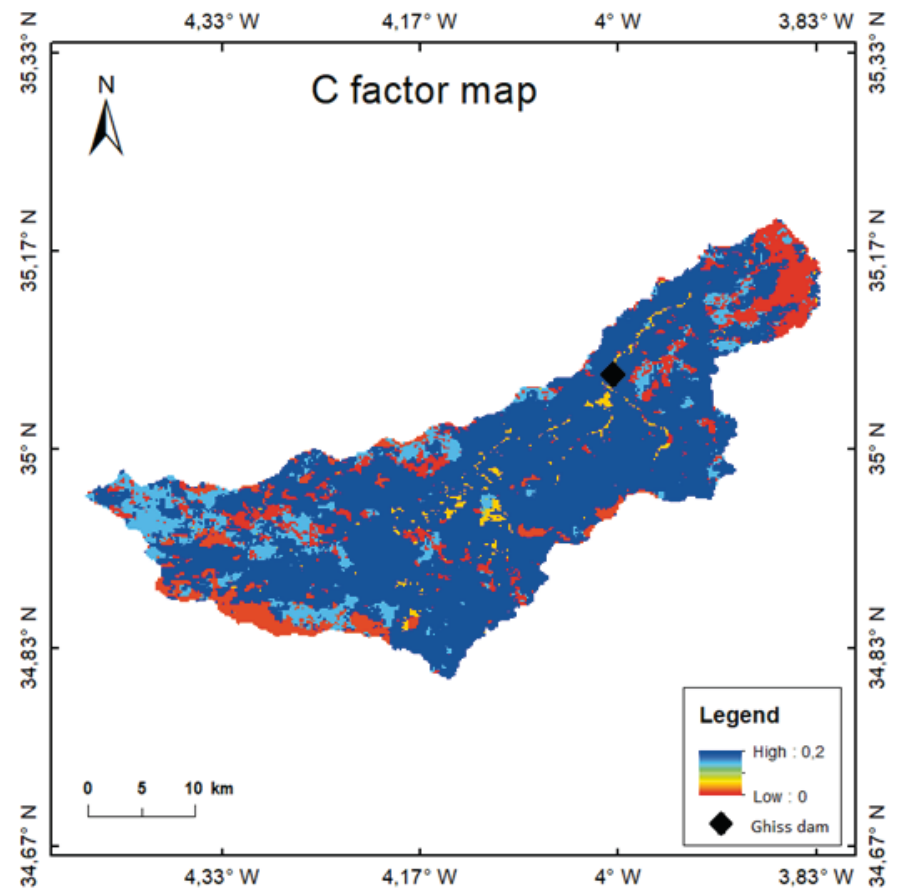

Fig. 8. $C$ factor of study area 


\subsection{Conservation Practice Factor $(P)$}

The $P$ factor map was derived from the LULC [37] and support factors [17]. The resultant map was converted to a grid map of $100 \mathrm{~m}$ cell size. The values of the $P$ factor range from 0.56 to 1 (Fig. 9), in which the high value is assigned to areas with no conservation practices; the minimum values correspond to urban land, trees, and crops.

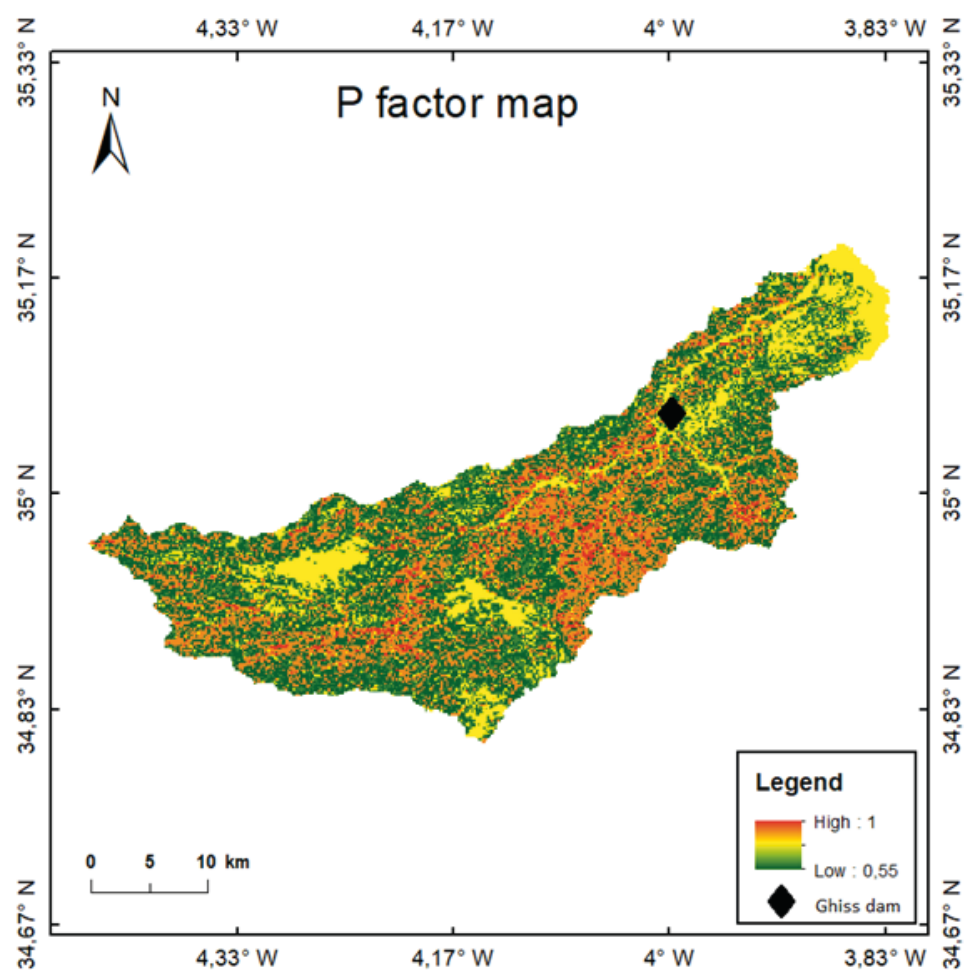

Fig. 9. $P$ factor of study area

\section{Results and Discussion}

The average annual soil erosion potential $(A)$ of the Ghiss basin is shown in Figure 10, and was obtained by integrating all raster factors data using Equation (1). The minimum and maximum losses are respectively about 0 and $19.5 \mathrm{t} \cdot \mathrm{ha}^{-1} \cdot \mathrm{yr}^{-1}$ (Fig. 10).

Previous work on the same watershed using the RUSLE method revealed that the annual soil loss is more than $30.1 \mathrm{t} \cdot \mathrm{ha}^{-1} \cdot \mathrm{yr}^{-1}$ [38]. Regarding other watersheds in the Rif region: the annual soil loss in the Nekor watershed using the RUSLE model is more than $37.2 \mathrm{t} \cdot \mathrm{ha}^{-1} \cdot \mathrm{yr}^{-1}$ [38], according to the RUSLE 3D model 
it is $60.77 \mathrm{t} \cdot \mathrm{ha}^{-1} \cdot \mathrm{yr}^{-1}[11]$, and the USPED model puts it at $65.86 \mathrm{t} \cdot \mathrm{ha}^{-1} \cdot \mathrm{yr}^{-1}[16]$. The annual soil loss in the Makhazen watershed using the USLE model is $735 \mathrm{t} \cdot \mathrm{ha}^{-1} \cdot \mathrm{yr}^{-1}$ [17]. These examples of soil loss estimation in the Rif region vary from one basin to another and even in the same watershed. This difference is due to many factors: the model used to estimate soil erosion, the physical characteristics of each basin, the chosen precipitation period ( $R$ factor).

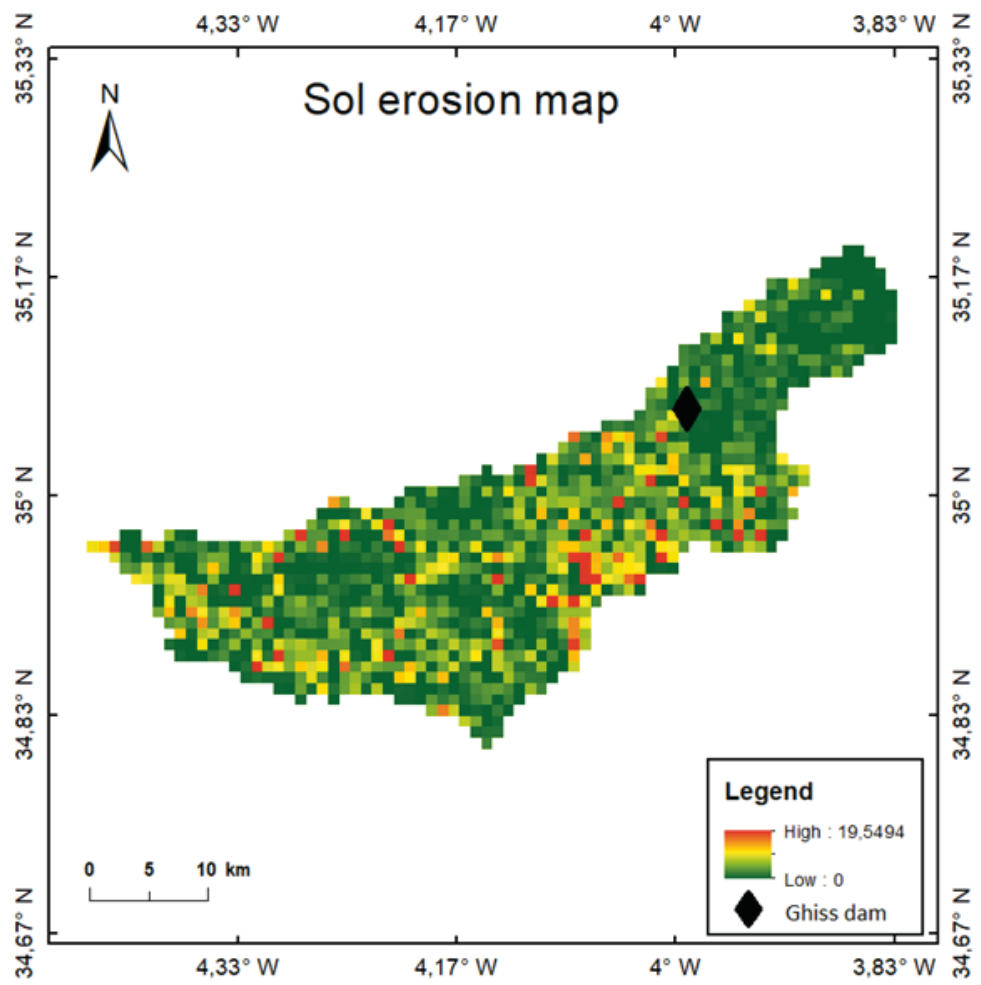

Fig. 10. The soil loss map of study area

To facilitate the selection of the anti-erosion area, the Ghiss watershed was classified into three spots according to soil erosion risk categories (low, moderate, high). Using these erosion risk classes (Fig. 11), it is observed that $98 \%$ of the area basin was classified as low erosion risk spots (Tab. 4), because of scrub, which is the dominant cover class in the study area, and protects the soil in different ways, including the interception of raindrops and the provision of organic carbon [39, 40]. Nevertheless, the low percentage $(1.47 \%)$ of soil erosion hot spots (moderate and high classes), can lead to Ghiss dam siltation because of its location at the top of the dam. To prevent the dam from siltation, it is necessary to conduct anti-erosion work upstream of the Ghiss dam, such as terrace farming and reforestation. 


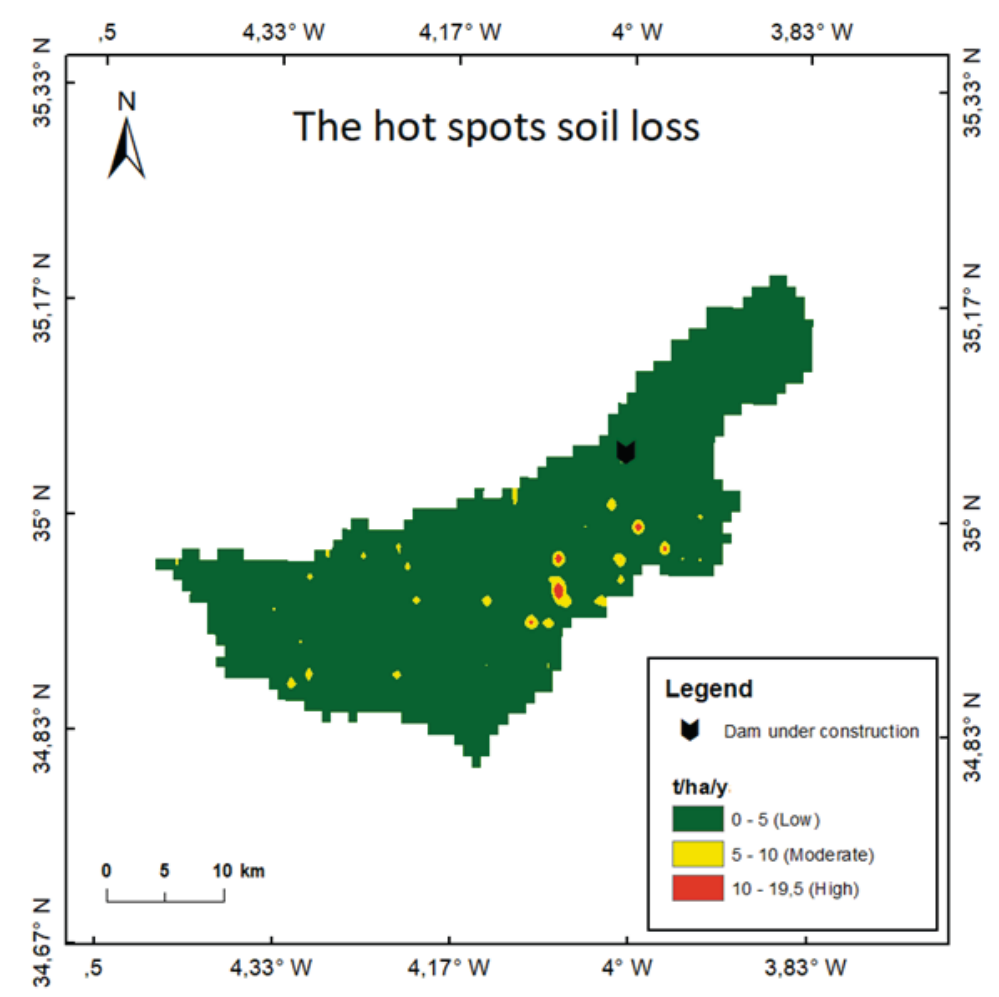

Fig. 11. The soil loss hot spot map of the study area

Table 4. The soil loss classification spots according to area and percentage

\begin{tabular}{|l|c|c||}
\hline \multicolumn{1}{|c|}{ Class } & Area [ha] & Area [\%] \\
\hline \hline Low & $83,346.16$ & 98.52 \\
\hline Moderate & $1,118.37$ & 1.32 \\
\hline High & 130.07 & 0.15 \\
\hline
\end{tabular}

\section{Conclusion}

This study estimated annual soil loss rate ranges, using the USLE model and GIS environment, to be between 0 and $19 \mathrm{t} \cdot \mathrm{ha}^{-1} \cdot \mathrm{yr}^{-1}$. The results of this study may help guide managers in selecting erosion area hot spots to be addressed in anti-erosion management to preserve the storage capacity of the Ghiss dam and to reduce the negative economic and environmental consequences of dam siltation. However, it must be noted the uncertainties regarding soil and climate data may have impacted soil loss estimates. 


\section{Acknowledgments}

We highly acknowledge the contributions of the reviewers and editors for their remarks which helped to improve the quality of this manuscript.

\section{References}

[1] Keller A., Sakthivadivel R., Seckler D.: Water scarcity and the role of storage in development. IWMI Research Report 39, International Water Management Institute, Colombo, Sri Lanka 2000.

[2] Haut Commissariat aux Eaux et Forêts et à la Lutte Contre la Désertification: Plan National d'Aménagement des Bassins Versants: Résumé et conclusions du rapport de synthèse. http://www.abhatoo.net.ma/content/download/28357/ 612736/version/1/file/Plan+National+d\%E2\%80\%99Am\%C3\%A9nagement+ des+Bassins+Versants [access: 1.09.2021].

[3] Jebari S., Berndtsson R., Bahri A., Boufaroua M.: Spatial soil loss risk and reservoir siltation in semi-arid Tunisia. Hydrological Sciences Journal, vol. 55(1), 2010, pp. 121-137. https://doi.org/10.1080/02626660903529049.

[4] Parveen R., Kumar U.: Integrated Approach of Universal Soil Loss Equation (USLE) and Geographical Information System (GIS) for Soil Loss Risk Assessment in Upper South Koel Basin, Jharkhand. Journal of Geographic Information System, vol. 4, 2012, pp. 588-596. https://doi.org/10.4236/jgis.2012.46061.

[5] Sharma R., Sahai B., Karale R.L.: Identification of Erosion Prone Areas in Part of the Ukai Catchment. [in:] Proceedings of the Sixth Asian Conference on Remote Sensing: Nov. 21-26, 1985, Hyderabad, India, Asian Conference on Remote Sensing, 1985, pp. 121-126.

[6] Bunyasi M.M., Onywere S.M., Kigomo M.K.: Sustainable Catchment Management: Assessment of Sedimentation of Masinga Reservoir and Its Implication on the Dam's Hydropower Generation Capacity. International Journal of Humanities and Social Science, vol. 3, no. 9, 2013, pp. 166-179.

[7] Bouziani M., Boucht F., Nouri F.: Contribution of bathymetric multi-beam sonar and laser scanners in $3 d$ modeling and estimation of siltation of dam basin in Morocco. The International Archives of the Photogrammetry, Remote Sensing and Spatial Information Sciences, vol. XLVI-4/W4-2021, 2021, pp. 5-9. https://doi.org/10.5194/isprs-archives-XLVI-4-W4-2021-5-2021.

[8] Sbai A., Mouadili O., Hlal M., Benrbia K., Zahra Mazari F., Bouabdallah M., Saidi A.: Water Erosion in the Moulouya Watershed and its Impact on Dams' Siltation (Eastern Morocco). Proceedings of the International Association of Hydrological Sciences, vol. 384, 2021, pp. 127-131. https://doi.org/10.5194/piahs-384-127-2021.

[9] Faleh A., Navas A., Sadiki A.: Erosion and dam siltation in a Rif catchment (Morocco). [in:] Horowitz A.J., Walling D.E. (eds.), Sediment Budgets 2, IAHS Publication, 292, IAHS Press, Wallingford 2005, pp. 58-64. 
[10] Alahiane N., Elmouden A., Aitlhaj A., Boutaleb A.: Small dam reservoir siltation in the Atlas Mountains of Central Morocco: analysis of factors impacting sediment yield. Environmental Earth Sciences, vol. 75, 2016, 1035. https://doi.org/ 10.1007/s12665-016-5795-y.

[11] El Gaatib R., Larabi A.: Integrated Evaluation of Soil Erosion Hazard and Risk Management in the Oued Beht Watershed Using Remote Sensing and GIS Techniques: Impacts on El Kansra Dam Siltation (Morocco). Journal of Geographic Information System, vol. 06(06), 2014, pp. 677-689. https://doi.org/10.4236/ jgis.2014.66056.

[12] Arrebei N., Sabir M., Naimi M., Chikhaoui M., Raclot D.: Reconstitution des données historiques et diagnostic de l'état actuel des aménagements antiérosifs dans le bassin versant Nekor. Revue Marocaine des Sciences Agronomiques et Vétérinaires, vol. 7(2), 2019, pp. 267-272.

[13] Lahlou A.: Specific Degradation of Watershed in Morocco. Report № 1000, Ministry of Equipment and National Promotion, Water Direction, Exploitation Division, Water Management Service, Rabat 1977.

[14] Ait Fora A.: Modélisation Spatiale de l'Erosion Hydrique dans un Bassin Versant du Rif Marocain: Validation de l'Approche Géomatique par la Sédimentologie, les Traceurs Radio-Actifs et la Susceptibilité Magnétique des Sédiment. Université de Sherbrooke, Quebec 1995 [Ph.D. thesis].

[15] Endalamaw N.T., Moges M.A., Kebede Y.S., Alehegn B.M., Sinshaw B.G.: Potential soil loss estimation for conservation planning, upper Blue Nile Basin, Ethiopia. Environmental Challenges, vol. 5, 2021, 100224. https://doi.org/10.1016/ j.envc.2021.100224.

[16] Arrebei N., Sabir M., Naimi M., Chikhaoui M., Raclot D.: Assessment of Soil Erosion with RUSLE 3D and USPED in the Nekor Watershed (Northern Morocco). Open Journal of Soil Science, vol. 10, no. 12, 2020, pp. 631-642. https://doi.org/ 10.4236/ojss.2020.1012031.

[17] Belasri A., Lakhouili A.: Estimation of Soil Erosion Risk Using the Universal Soil Loss Equation (USLE) and Geo-Information Technology in Oued El Makhazine Watershed, Morocco. Journal of Geographic Information System, vol. 8, 2016, pp. 98-107. https://doi.org/10.4236/jgis.2016.81010.

[18] Tahiri M., Tabyaoui H., Tahiri A., El Hadi H., El Hammichi F., Achab M.: Modelling Soil Erosion and Sedimentation in the Oued Haricha Sub-Basin (Tahaddart Watershed, Western Rif, Morocco): Risk Assessment. Journal of Geoscience and Environment Protection, vol. 04(01), 2016, pp. 107-119. https://doi.org/ 10.4236/gep.2016.41013.

[19] Wischmeier W.H., Smith D.D.: Predicting Rainfall Erosion Losses: A Guide to Conservation Planning. Agriculture Handbook, 537, U.S. Department of Agriculture, 1978. 
[20] Bourjila A., Dimane F., El Ouarghi H., Nouayti N., Taher M., El Hammoudani Y., Saadi O., Bensiali A.: Groundwater potential zones mapping by applying GIS, remote sensing and multi-criteria decision analysis in the Ghiss basin, northern Morocco. Groundwater for Sustainable Development, vol. 15, 2021, 100693. https://doi.org/10.1016/j.gsd.2021.100693.

[21] Ali S.A., Hagos H.: Estimation of soil erosion using USLE and GIS in Awassa Catchment, Rift valley, Central Ethiopia. Geoderma Regional, vol. 7(2), 2016, pp. 159-166. https://doi.org/10.1016/j.geodrs.2016.03.005.

[22] Devatha C.P., Deshpande V., Renukaprasad M.S.: Estimation of Soil loss Using USLE Model for Kulhan Watershed, Chattisgarh - A Case Study. Aquatic Procedia, vol. 4, 2015, pp. 1429-1436. https://doi.org/10.1016/j.aqpro.2015.02.185.

[23] George K.J., Kumar S., Hole R.M.: Geospatial modelling of soil erosion and risk assessment in Indian Himalayan region - A study of Uttarakhand state. Environmental Advances, vol. 4, 2021, 100039. https://doi.org/10.1016/j.envadv. 2021.100039.

[24] Kertész Á.: Application of GIS methods in soil erosion modelling. Computers, Environment and Urban Systems, vol. 17(3), 1993, pp. 233-238. https://doi.org/ 10.1016/0198-9715(93)90018-Z.

[25] Lahlaoi H., Rhinane H., Hilali A., Lahssini S., Khalile L.: Potential Erosion Risk Calculation Using Remote Sensing and GIS in Oued El Maleh Watershed, Morocco. Journal of Geographic Information System, vol. 7, 2015, pp. 128-139. https://doi.org/10.4236/jgis.2015.72012.

[26] Mhaske S.N., Pathak K., Dash S.S., Nayak D.B.: Assessment and management of soil erosion in the hilltop mining dominated catchment using GIS integrated RUSLE model. Journal of Environmental Management, vol. 294, 2021, 112987. https://doi.org/10.1016/j.jenvman.2021.112987.

[27] Olorunfemi I.E., Komolafe A.A., Fasinmirin J.T., Olufayo A.A., Akande S.O.: A GIS-based assessment of the potential soil erosion and flood hazard zones in Ekiti State, Southwestern Nigeria using integrated RUSLE and HAND models. Catena, vol. 194, 2020, 104725. https://doi.org/10.1016/j.catena.2020.104725.

[28] Pham T.G., Degener J., Kappas M.: Integrated universal soil loss equation (USLE) and Geographical Information System (GIS) for soil erosion estimation in A Sap basin: Central Vietnam. International Soil and Water Conservation Research, vol. 6(2), 2018, pp. 99-110. https://doi.org/10.1016/j.iswcr.2018.01.001.

[29] Nguyen T.H.: Identify the factors effect to soil erosion and forecast soil erosion on slope land. Water Resources University of Vietnam (Thuyloi University), Hanoi 1996 [Ph.D. thesis, in Vietnamese].

[30] Fick S.E., Hijmans R.J.: WorldClim 2: new 1-km spatial resolution climate surfaces for global land areas. International Journal of Climatology, vol. 37(12), 2017, pp. 4302-4315. https://doi.org/10.1002/joc.5086. 
[31] Shabani F., Kumar L., Esmaeili A.: Improvement to the prediction of the USLE K factor. Geomorphology, vol. 204, 2014, pp. 229-234. https://doi.org/10.1016/ j.geomorph.2013.08.008.

[32] Millward A.A., Mersey J.E.: Adapting the RUSLE to model soil erosion potential in a mountainous tropical watershed. Journal of Catena, vol. 38(2), 1999, pp. 109-129. https://doi.org/10.1016/S0341-8162(99)00067-3.

[33] Moore I.D., Wilson J.P.: Length-slope factors for the revised universal soil loss equation: Simplified method of estimation. Journal of Soil and Water Conservation, vol. 47(5), 1992, pp. 423-428.

[34] Knijff J.M., Jones R.J.A., Montanarella L.: Soil erosion risk assessment in Europe. EUR 19044 EN, Joint Research Centre, European Commission, 2000.

[35] Hurni H.: Soil Conservation: Manual for Ethiopia (first draft): A Field Guide for Conservation Implementation. Community Forests and Soil Conservation Development Department, Addis Ababa 1985.

[36] Reusing M., Schneider T., Ammer U.: Modeling soil loss rates in the Ethiopian highlands by integration of high-resolution MOMS-02/D2-stereo-data in a GIS. International Journal of Remote Sensing, vol. 21(9), 2000, pp. 1885-1896. https://doi.org/10.1080/014311600209797.

[37] Karra K., Kontgis C., Statman-Weil Z., Mazzariello J.C., Mathis M., Brumby S.P.: Global land use / land cover with Sentinel 2 and deep learning. [in:] 2021 IEEE International Geoscience and Remote Sensing Symposium IGARSS, 2021, pp. 4704-4707. https://doi.org/10.1109/IGARSS47720.2021.9553499.

[38] Salhi A., Benabdelouahab T., Okacha A., Martín-Vide J., El Hasnaoui Y., El Mousaoui M., El Morabit A., Himi M., Benabdelouahab S., Lebrini Y., Boudhar A., Casas A.: Bridging the gap of perception is the only way to align soil. Science of the Total Environment, vol. 718, 2020, 137421. https://doi.org/ 10.1016/j.scitotenv.2020.137421.

[39] Casermeiroa M.A., Molinab J.A., Caravaca M.T., Costa J., Massanet M.I., Moreno P.: Influence of scrubs on runoff and sediment loss in soils of Mediterranean climate. Catena, vol. 57, 2004, pp. 91-107. https://doi.org/10.1016/S03418162(03)00160-7.

[40] Bochet E., Poesen J., Rubio J.L.: Runoff and soil loss under individual plants of a semi-arid Mediterranean shrubland: influence of plant morphology and rainfall intensity. Earth Surface Processes and Landforms, vol. 31, 2006, pp. 536-549. https://doi.org/10.1002/esp.1351. 